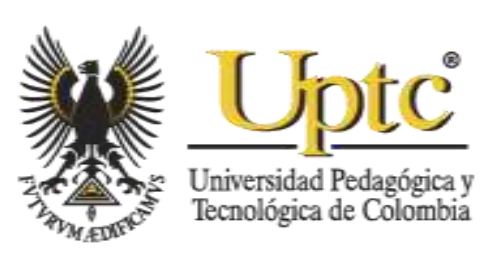

\title{
Numerical Study of a Helical Heat Exchanger for Wort Cooling in the \\ Artisanal Beer Production Process
}

Fernando Toapanta-Ramos; Luis González-Rojas; Elmo Calero; Bryan Calderón; William Quitiaquez

Citation: F. Toapanta-Ramos, L. González-Rojas, E. Calero, B.

Calderón, W. Quitiaquez, "Numerical Study of a Helical Heat Exchanger for Wort Cooling in the Artisanal Beer Production Process," Revista Facultad de Ingeniería, vol. 29 (54), e11632, 2020. https://doi.org/10.19053/01211129.v29.n54.2020.11632

Received: August 27, 2020; Accepted: November 23, 2020; Published: November 24, 2020

Copyright: This is an open access article distributed under license $\underline{\mathrm{CC} B Y}$

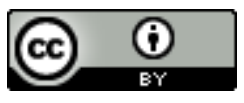

Conflict of interest: The authors state there is no conflict of interest. 


\title{
Numerical Study of a Helical Heat Exchanger for Wort Cooling in the Artisanal Beer Production Process
}

\author{
Fernando Toapanta-Ramos ${ }^{1}$ \\ Luis González-Rojas² \\ Elmo Calero ${ }^{3}$ \\ Bryan Calderón ${ }^{4}$ \\ William Quitiaquez ${ }^{5}$
}

\begin{abstract}
The objective of the present work is to study the behavior of a helical tube and shell heat exchanger, for the cooling of the wort in the process of making craft beer with cold water, through the methodology of computational fluid dynamics (CFD) by finite volume models for heat exchanger modeling. This by using the ANSYS Fluent software, which allows to understand the behavior of the fluid through equations that describe their movement and behavior, using numerical methods and computational techniques. In the mesh convergence, two methods were used, orthogonality and obliquity, with which it was confirmed that the meshing is ideal in the simulations that were carried out. For the simulation, the k-epsilon turbulence model and the energy model were used. Through various simulations, it was obtained that by varying the mass flow, better results are reducing the outlet temperature, with a variation of $15.16^{\circ} \mathrm{C}$, while varying the inlet temperature of the water, there is just a variation
\end{abstract}

1 M. Sc. Universidad Politécnica Salesiana (Quito, Ecuador). Itoapanta@ups.edu.ec. ORCID: 0000-0002-0838-4702

2 Universidad Politécnica Salesiana (Quito, Ecuador). Igonzalezr1@est.ups.edu.ec. ORCID: 0000-0001-65734353

${ }^{3}$ Universidad Politécnica Salesiana (Quito, Ecuador). ecalerp@est.ups.edu.ec. ORCID: 0000-0001-5595-5005

${ }^{4}$ Universidad Politécnica Salesiana (Quito, Ecuador). bcalderons@est.ups.edu.ec. ORCID: 0000-0002-86023099

${ }^{5}$ M. Sc. Universidad Politécnica Salesiana (Quito, Ecuador). wquitiaquez@ups.edu.ec. ORCID: 0000-00019430-2082

Revista Facultad de Ingeniería (Rev. Fac. Ing.) Vol. 29 (54), e11632. 2020. Tunja-Boyacá, Colombia.

L-ISSN: 0121-1129, e-ISSN: 2357-5328, DOI: https://doi.org/10.19053/01211129.v29.n54.2020.11632 
from $2.71^{\circ} \mathrm{C}$ to $0.01{ }^{\circ} \mathrm{C}$. Therefore, a significant improvement in the performance of the heat exchanger was found. In the same way, it was confirmed that the number of spikes in the heat exchanger is adequate, since the outlet temperature would not be reached with less spikes.

Keywords: CFD; heat interchanger; helical tube; wort.

\section{Estudio numérico de un intercambiador de calor helicoidal para el enfriamiento del mosto en el proceso de elaboración de cerveza artesanal}

\section{Resumen}

El presente trabajo tiene como objetivo estudiar el comportamiento de un intercambiador de calor de tubo helicoidal y coraza, para el enfriamiento del mosto en el proceso de elaboración de cerveza artesanal con agua fría, mediante la metodología de dinámica de fluidos computacional (CFD) por volúmenes finitos para el modelado del intercambiador de calor. Esto utilizando el software Fluent de ANSYS, mismo que nos permite comprender el fluido a través de ecuaciones que describen su movimiento y su comportamiento, mediante métodos numéricos y técnicas computacionales. En la convergencia de malla se manejaron dos métodos, ortogonalidad y oblicuidad, en los que se corroboró que el mallado es ideal en las simulaciones que se realizaron. Para la simulación se empleó el modelo de turbulencia k-épsilon y el modelo de energía. Por medio de varias simulaciones se obtuvo que, mediante la variación del flujo másico del mosto, se obtienen mejores resultados en la reducción de temperatura de salida, donde existe una variación de $15.16^{\circ} \mathrm{C}$. Por otro lado, variando la temperatura de entrada del agua, existe apenas una variación de $2.71^{\circ} \mathrm{C} \mathrm{a} 0.01^{\circ} \mathrm{C}$. Por lo tanto, se encontró una mejora significativa en el funcionamiento del intercambiador de calor. De la misma forma, se confirmó que el número de espigas en el intercambiador de calor es el adecuado, ya que con menos no se alcanzaría la temperatura de salida.

Palabras clave: CFD; intercambiador de calor; mosto; tubo helicoidal. 


\section{INTRODUCTION}

Beer is one of the most consumed beverages in the world and the most popular among alcoholic ones [1-3], it has been present in human life for thousands of years [1, 3-6], and its popularity has grown throughout history. Because of this, the focus on improvements in its production becomes essential.

In the production of beer, the aim is to improve the methods to obtain a quality product, from the preparation of an established formula, to the treatment of the drink in each of the stages. Rodman [7] recognizes fermentation as the most important process when brewing beer, therefore, it is sought to improve the production times of this stage and generate a better yield [8], [9]. Specifically, through improvements in cooling, after the wort boil.

The cooling of the hot wort must be carried out as quickly as possible to avoid the formation of microorganisms or bacteria [1, 3, 5, 10-11], regarding the range of temperatures, Agulló [12] clarifies that it goes from $15^{\circ} \mathrm{C}$ to $25^{\circ} \mathrm{C}$, when the yeast is alive. This process requires a lot of time and energy, due to this, shortening its duration and cost implies enormous potential savings [8]; generally, this energy saving is intended through improvements in heat exchangers.

In the brewing industry the cooling process is commonly carried out using plate heat exchangers [13], due to the fact that they are easy to assemble and clean; also, since they are easily opened, they allow the inspection of the entire heat transfer surface [14]. During the heat exchange, incrustations or fouling are generated [15], which result from the caramelized layer of sugars on the surface [5] that reduces the efficiency of the heat exchanger [16].

Qiu and Qiu [17] made a machine for the cooling of craft beer through tubes assembled in a helical way, where a fresh and refrigerated product can be obtained directly from the tap. In turn, they affirmed that conventional machines have the problem of being slow or distributing fluids with low speeds, which is solved by using a system of tubes assembled in a helical way in different distributions, the first creating an internal coil (beer flow) and an external coil (cooling flow). In the other case, both coils were set collinearly, one on top of the other, where the second case obtained the best efficiency.

Revista Facultad de Ingeniería (Rev. Fac. Ing.) Vol. 29 (54), e11632. 2020. Tunja-Boyacá, Colombia. L-ISSN: 0121-1129, e-ISSN: 2357-5328, DOI: https://doi.org/10.19053/01211129.v29.n54.2020.11632 
On the other hand, Liu et al. [18] clarify that all the favorable parameters and, therefore, the efficiency, improve when reducing the diameter of the spiral and increase the pitch of the helical tubes. This by comparing the hydrodynamic performance of a multi-tube helical heat exchanger (MTTHC), between experimental results and CFD simulation. The validation of its data is obtained through an error of $9.81 \%$ in pressure and $7.6 \%$ in temperature, with respect to the experimental investigation.

Wang et al. [19] carried out a comparison of the obtained experimental results using CFD software for a helically assembled trilobed tube heat exchanger (HCTTT), the tests were carried out with Reynolds number ranges of 2000-40000. Errors were obtained of less than $5 \%$ in heat parameters $(Q)$, convection heat transfer coefficient (h), Nusselt number $(\mathrm{Nu})$, and friction factor (f), which makes the research credible. The experiment includes an analysis of HCPT, HCET, and HCTT exchangers with the same diameter of $6 \mathrm{~mm}$, and it was obtained that the thermal performance is higher in the HCTTT up to a maximum of 1.22 times, which increases proportionally to the Reynolds.

El-said et al. [20] compares the results of a helical plate heat exchanger (HPHE) with a Reynolds range of 2000-7000 in hot fluid and 1400-7000 in cold fluid, as well as a passage radius of $0.24-1.31$, obtaining that the efficiency varies from 0.1758 to 0.6756 in the established intervals. The error maintained is $13 \%$ compared to the experimental data, in addition, it affirms that all the parameters improve, except for the pressure, where there is a slight drop.

Hatef and Ranjbar [21] observed, in their study of the effect of geometric parameters on heat transfer and hydrodynamics characteristics of the helical exchanger, that the heat transfer coefficient increases in relation to the internal diameter of the tube and bending ratio, and due to the decrease in the pitch of the coil. This study is developed by validating the numerical data obtained with the experimental model, using a double helical tube exchanger for their study. As for the Nusselt number, it is affected by the increase in the radius of the exchanger coil [22], resulting in a decrease in the global heat transfer coefficient. 
The present research aims to establish the appropriate parameters to reduce the temperature of the beer wort in the shortest possible time, through a CFD simulation, considering water as a cooling fluid, in a helical tube and shell heat exchanger.

\section{MEthods AND MATERIALS}

The brewing process is composed of different stages, such as preheating, mashing, hops, cooling, heat exchange, fermentation and, finally, gasification. The heat exchanger is the central part of this analysis and where the fluid is subjected to different changes. The process begins with the preheating of the water, so that it meets the input conditions prior to the maceration; at this point, the grains are added and are taken to a cooking process that allows to obtain the wort, which represents the object of study. This wort will be cooled through the heat exchanger, ensuring that the cooling takes place in the shortest possible time and that the gasification process can continue, where the beer preparation ends.

The fluid with the highest temperature is the wort, which enters the heat exchanger at a temperature of $70{ }^{\circ} \mathrm{C}$ in the helical geometry tube, while the water used for cooling enters the shell at $15^{\circ} \mathrm{C}$. This process is shown in Figure 1 , the outlet temperature of the wort exchanger should be $25^{\circ} \mathrm{C}$ for high fermentation ale of beer type.

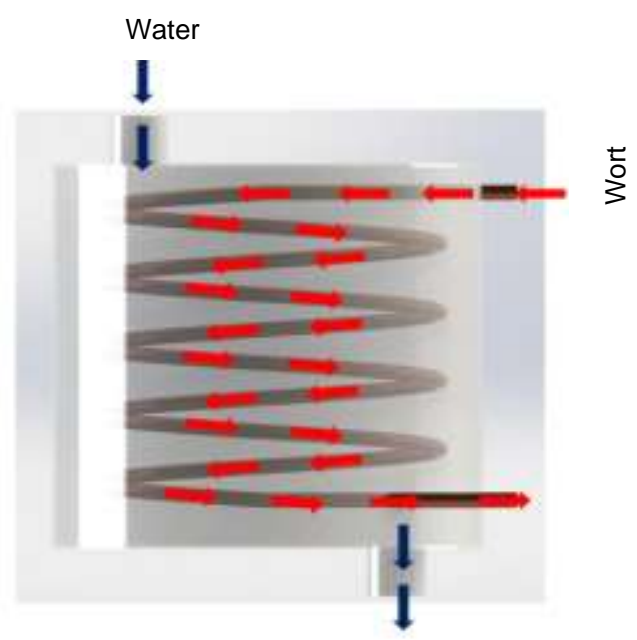

Fig. 1. Helical tube and shell heat exchanger operating diagram. 


\section{A. System Description}

The research has foreseen the design of a shell and helical tube heat exchanger. The material used in the design of the shell is commercial steel, while DHP type L copper is considered for the helical tube.

The shape of the helical tube is described with two geometric parameters, the pitch $p$ and the radius of the helix $\mathrm{Rh}$, the selection of the shell exchanger is due to the fact that the hot fluid wort does not contact the cooling fluid that circulates through the geometry of the shell.

One of the most important factors in the fluid cooling process is the correct selection of the geometry of the heat exchanger and especially of the helical tube. The geometric dimensions selected for the system are specified in Table 1.

Table 1. Dimensions of the heat exchanger.

\begin{tabular}{|l|l|c|c|}
\hline \multicolumn{1}{|c|}{ Geometry } & & Parameter & Value (m) \\
\hline \multirow{4}{*}{ Helical Tube } & Outside diameter & $D_{e}$ & 0.015 \\
\cline { 2 - 4 } & Inside diameter & $D_{i}$ & 0.01339 \\
\cline { 2 - 4 } & Coil diameter & $D_{c}$ & 0.320 \\
\cline { 2 - 4 } & Effective length & $L_{e}$ & 0.320 \\
\cline { 2 - 4 } & Helix pitch & $\mathrm{P}$ & 0.07111 \\
\hline \multirow{4}{*}{ Shell } & Shell length & LS & 0.400 \\
\cline { 2 - 4 } & Shell diameter & DS & 0.350 \\
\cline { 2 - 4 } & Shell outer diameter & DES & 0.03 \\
\cline { 2 - 4 } & Internal shell diameter & DIS & 0.04 \\
\hline
\end{tabular}

\section{B. Description of Working Fluids}

To generate a system that can be applied, the study parameters are established through the type $L$ copper and steel commercial materials. The thermodynamic properties of the materials are shown in Table 2, for calculation purposes the thermodynamic properties are considered as pure copper, since DHP copper has a purity greater than $99 \%$. 
Fernando Toapanta-Ramos; Luis González-Rojas; Elmo Calero; Bryan Calderón; William Quitiaquez

Table 2. Thermodynamic properties of exchanger materials [23].

\begin{tabular}{|c|c|c|c|}
\hline Material & $\mathrm{Cp}\left(\mathrm{J} \mathrm{kg}^{-1} \mathrm{~K}^{-1}\right)$ & $\mathrm{k}\left(\mathrm{W} \mathrm{m}^{-2} \mathrm{~K}^{-1}\right)$ & $\rho\left(\mathrm{kg} \mathrm{m}^{-3}\right)$ \\
\hline Copper type $\mathrm{L}$ & 385 & 401 & 8933 \\
\hline Steel & 434 & 60.5 & 7854 \\
\hline
\end{tabular}

On the other hand, Table 3 denotes the thermodynamic properties of hot and cold working fluids, such as beer wort and water, respectively.

Table 3. Thermodynamic properties of fluids [10], [23].

\begin{tabular}{|c|c|c|c|c|c|}
\hline Fluid & $\rho\left(\mathrm{kg} \mathrm{m}^{-3}\right)$ & $\mathrm{Cp}\left(\mathrm{J} \mathrm{Kg}^{-1} \mathrm{~K}^{-1}\right)$ & $\mathrm{k}\left(\mathrm{W} \mathrm{m}^{-2} \mathrm{~K}^{-1}\right)$ & $\mu\left(\mathrm{kg} \mathrm{m} \mathrm{s}^{-1}\right)$ & $\mathrm{Pr}$ \\
\hline Water & 999.1 & 4186 & 0.5890 & $1.138 \mathrm{E}-3$ & 8.09 \\
\hline Wort & 989.1 & 4187 & 0.6405 & $5.715 \mathrm{E}-4$ & 3.73 \\
\hline
\end{tabular}

Through this analysis, it is intended to obtain parameters of temperature and pressure at the outlet of the wort in the heat exchanger, the mesh shown in Figure 2 was obtained after establishing its application with several simulations as valid, and a mesh quality referring to the obliquity and orthogonality.

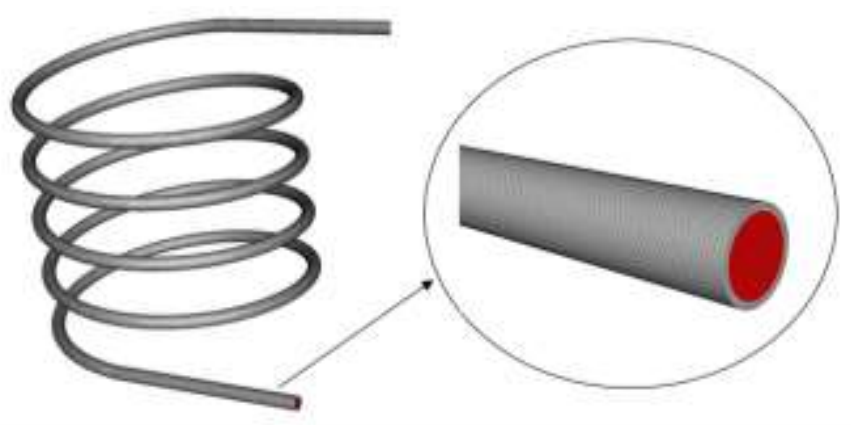

Fig. 2. Meshing of the exchanger.

The convergence of the skew mesh is shown in Figure 3, with an average of 0.20981. On the other hand, the mesh convergence in orthogonality presents an average of 0.82443 , with a minimum of 0.11565 , as shown in Figure 4 . The statistics obtained from the meshing of the heat exchanger correspond to 1696103 nodes with 3227323 elements. 


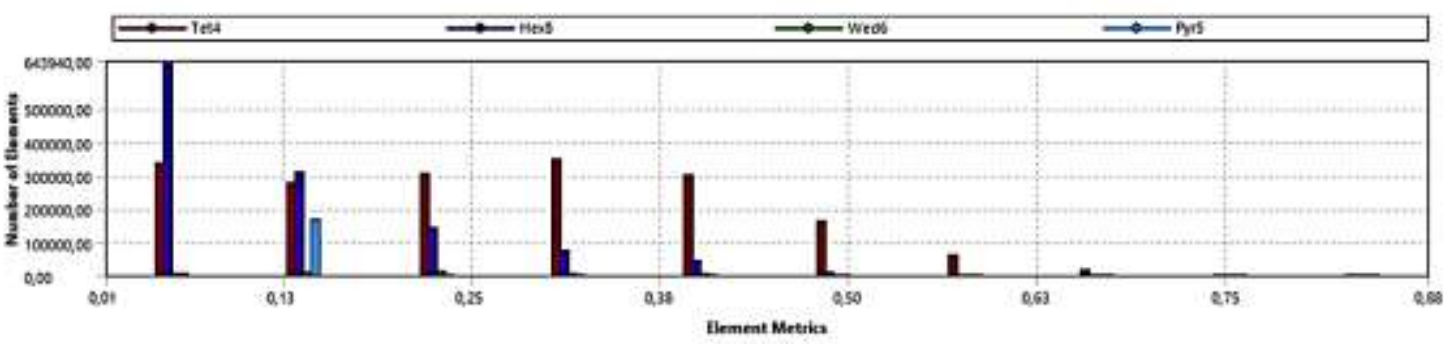

Fig. 3. Mesh convergence by obliquity.

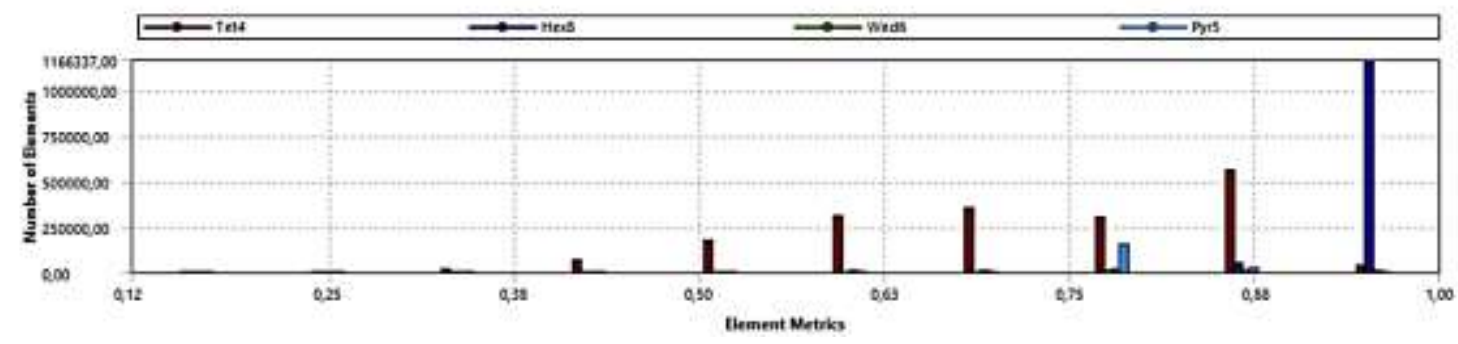

Fig. 4. Orthogonality meshing convergence.

\section{Simulation Model}

In helical tube modeling, the governing equations that correspond to the ANSYS Fluent 2019 software are considered, within which the k-epsilon RNG $(k-\varepsilon)$ turbulence model can be seen.

The fundamental continuity equations are based on Navier Stokes' concept of conservation of mass, momentum, and energy, obtained through numerical methods and expressed in equations $1,2,3$, respectively.

$$
\begin{gathered}
\frac{\partial \rho}{\partial t}+\nabla \rho \vec{v} r=0 \\
\frac{\partial}{\partial t}+\left(\rho E_{r}\right)+\nabla \cdot\left(\rho \vec{v}_{r} \vec{v}_{r}\right)+\rho\left(2 \vec{\omega} \times \vec{v}_{r}+\vec{\omega} \times \vec{\omega} \times \vec{r}+\vec{a} \times \vec{r}+\vec{a}\right)=-\nabla p+\nabla \cdot \bar{\tau}_{r}+\vec{F} \\
\frac{\partial}{\partial t}+\left(\rho E_{r}\right)+\nabla \cdot\left(\rho \vec{v}_{r} H_{r}\right)=\nabla \cdot\left(k \nabla T+\bar{\tau}_{r} \cdot \vec{v}_{r}\right)+S_{h}
\end{gathered}
$$

To calculate the equilibrium of moments, it is necessary to obtain the shear stress generated on the fluids, through equation 4.

$$
\bar{\tau}=\mu\left[\left(\nabla \vec{v}+\vec{v}^{T}\right)-\frac{2}{3} \nabla \cdot \vec{v} I\right]
$$

Due to the existence of curves in the studied model, the epsilon RNG kappa model is used. In equation 5 the turbulence model for kappa kinetic energy is presented.

$$
\frac{\partial}{\partial t}(\rho \mathrm{k})+\frac{\partial}{\partial x_{i}}\left(\rho \mathrm{k} u_{i}\right)=\frac{\partial}{\partial x_{j}}\left(\alpha_{k} \mu_{e f f} \frac{\partial k}{\partial x_{j}}\right)+\mathrm{G}_{\mathrm{k}}-\mathrm{G}_{b}-\rho \varepsilon-Y_{M}+S_{k}
$$


On the other hand, equation 6 represents the epsilon diffusivity in the turbulence model.

$$
\frac{\partial}{\partial t}(\rho \varepsilon)+\frac{\partial}{\partial x_{i}}\left(\rho \varepsilon u_{i}\right)=\frac{\partial}{\partial x_{j}}\left(\alpha_{\varepsilon} \mu_{e f f} \frac{\partial \varepsilon}{\partial x_{j}}\right)+C_{1 \varepsilon} \frac{\varepsilon}{k}\left(\mathrm{G}_{\mathrm{k}}+C_{3 \varepsilon} \mathrm{G}_{b}\right)-C_{2 \varepsilon} \rho \frac{\varepsilon^{2}}{k}-R_{\varepsilon}+S_{\varepsilon}(6)
$$

Within the calculation of helical tubes, centrifugal forces that influence the calculation factors are generated [24], specifically the Reynolds number, therefore, a relationship must be found to correct the deviation that exists due to the aforementioned forces. This relationship is called Dean's number and is obtained through equation 7 .

$$
D e=\operatorname{Re}\left(\frac{D_{h}}{D_{c}}\right)^{0.5}
$$

\section{RESULTS AND DISCUSSION}

The simulation starts under the k-epsilon RNG turbulence model, with mass flows of $0.7 \mathrm{~kg} \cdot \mathrm{s}^{-1}$ and $7.5 \mathrm{~kg} \cdot \mathrm{s}^{-1}$ for the wort and water, respectively, and with inlet conditions of $101325 \mathrm{~Pa}$ pressure and a temperature of $70^{\circ} \mathrm{C}$. Since it is a shell exchanger, 18 ${ }^{\circ} \mathrm{C}$ is set as the outside temperature, corresponding to the water flowing through the shell. Figure 5 shows the behavior of the helical tube with the indicated parameters.
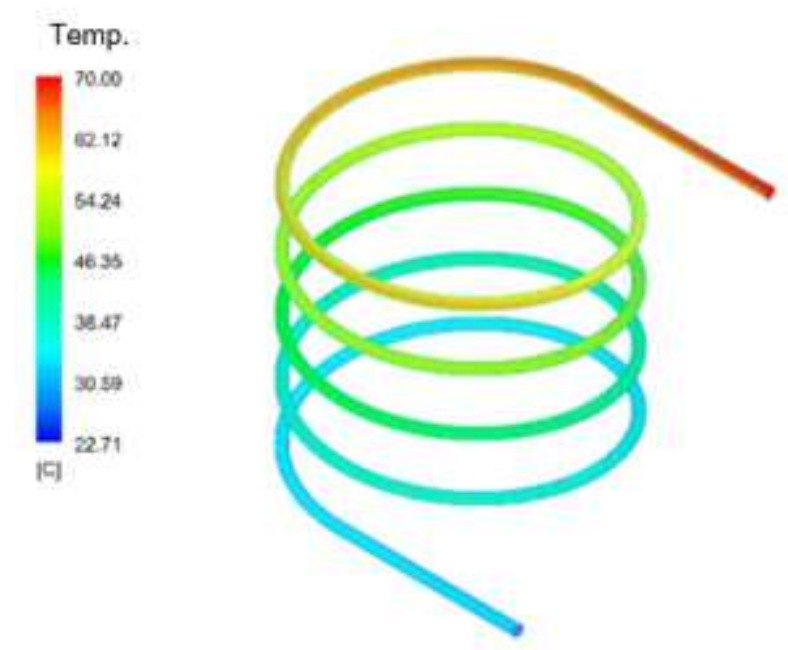

Fig. 5. Simulation 1 of the behavior of the wort in the helical tube. 
After performing the first simulation, an outlet temperature of $33.43^{\circ} \mathrm{C}$ is obtained, which does not correspond to the temperature expected to start the fermentation process.

In the search for the correct parameters for the heat exchanger established with the initial dimensions, the mass flow is reduced to $0.5 \mathrm{~kg} \cdot \mathrm{s}^{-1}$, maintaining the temperature and inlet flow for the water. The behavior of this simulation is shown in Figure 6.
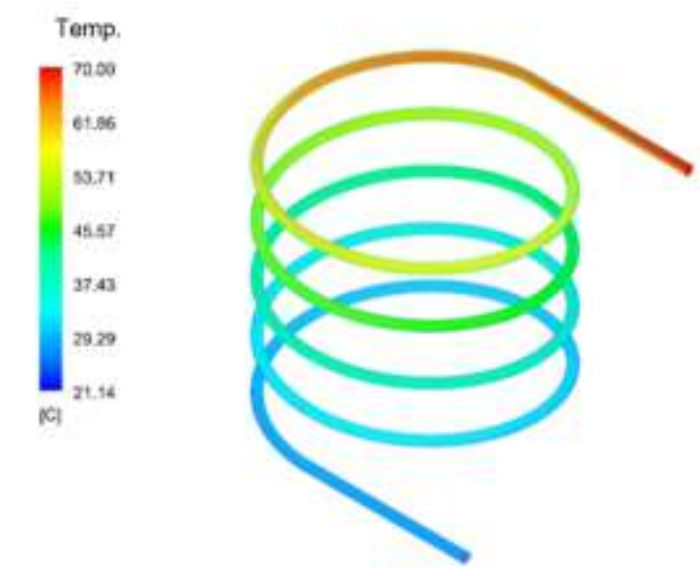

Fig. 6. Simulation 2, behavior of the wort in the helical tube.

The results obtained after the second simulation show a significant improvement, generating a wort outlet temperature of $28.54{ }^{\circ} \mathrm{C}$, satisfactorily approaching the expected result.

Regarding the parameters for the third simulation, an inlet mass flow was established for wort and water, of 0.2 and $7 \mathrm{~kg} \cdot \mathrm{s}^{-1}$, respectively; also, the water temperature is kept at $18{ }^{\circ} \mathrm{C}$. The generated behavior is shown in Figure 7 . 

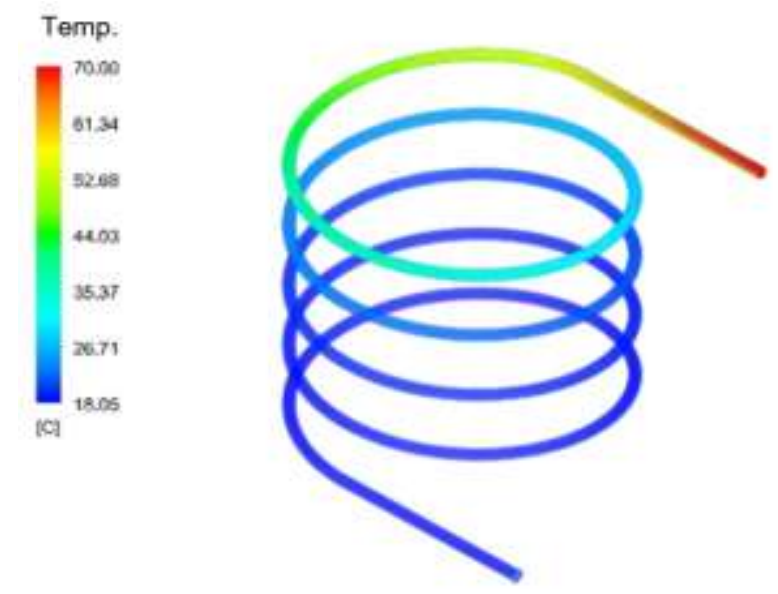

Fig. 7. Simulation 3, behavior of the wort in the helical tube.

The results obtained from the third simulation show that the outlet temperature of the wort dropped dramatically to $18.42^{\circ} \mathrm{C}$, exceeding the expected limit of $25^{\circ} \mathrm{C}$. The input parameters for simulation 4 are $2.5 \mathrm{~kg} \cdot \mathrm{s}^{-1}$ and $8 \mathrm{~kg} \mathrm{~s}^{-1}$ for the input mass flow of wort and water, respectively, while the water temperature does not change compared to the previous simulations. The behavior of the wort in the helical tube for the fourth simulation is shown in Figure 8. From the fourth simulation, a wort outlet temperature of $28.44{ }^{\circ} \mathrm{C}$ is obtained, which rises compared to simulation 3 . However, it falls away from the desired result again.
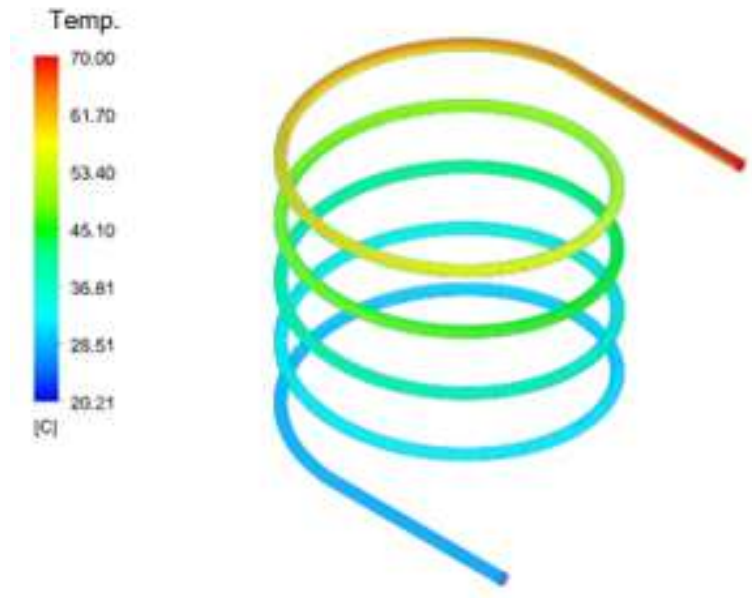

Fig. 8. Simulation 4, behavior of the wort in the helical tube. 
From the fifth simulation, the inlet temperature of the cooling water is considered an important variable, which is reduced to $15^{\circ} \mathrm{C}$, and the mass flows are considered just as in the first simulation: $0.7 \mathrm{~kg} \cdot \mathrm{s}^{-1}$ for wort and $7.5 \mathrm{~kg} \cdot \mathrm{s}^{-1}$ for water. The behavior of the wort in the helical tube for these parameters is shown in Figure 9.

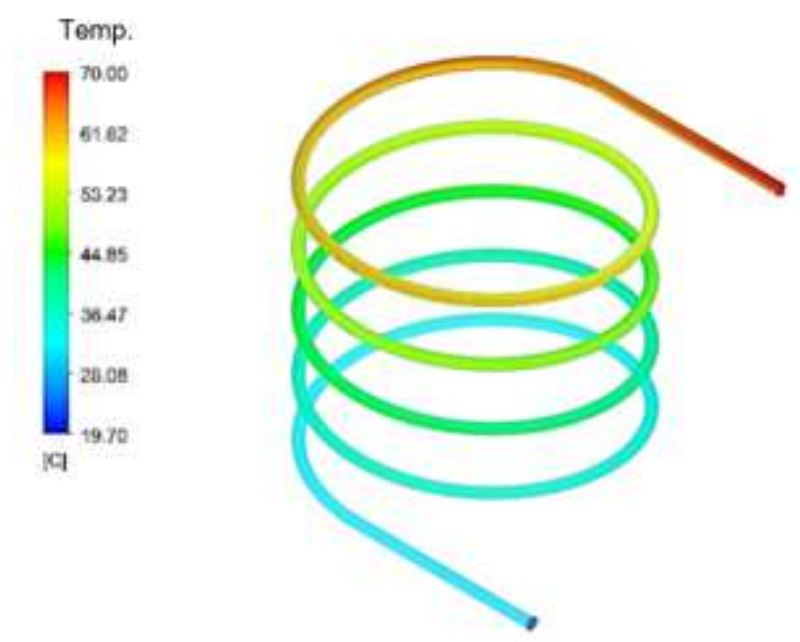

Fig. 9. Simulation 5, behavior of the wort in the helical tube.

With the new established parameters, a wort outlet temperature of $30.72{ }^{\circ} \mathrm{C}$ is obtained.

Continuing with the process of emulating the parameters of the initial simulations with the new water inlet temperature, the behavior of the tube is set at $0.5 \mathrm{~kg} \cdot \mathrm{s}^{-1}$ for wort, and $7.5 \mathrm{~kg} \cdot \mathrm{s}^{-1}$ for water. this behavior can be seen in Figure 10.

Simulation 6 shows a wort outlet temperature of $27.84^{\circ} \mathrm{C}$. The outlet temperature obtained with the simulation meets the requirement for the ale brewing process, a product established for the simulation. Although the change in the geometry of the helical tube [21] allows to obtain good results in terms of heat transfer, it is also necessary to consider the variations of the input mass flow. 

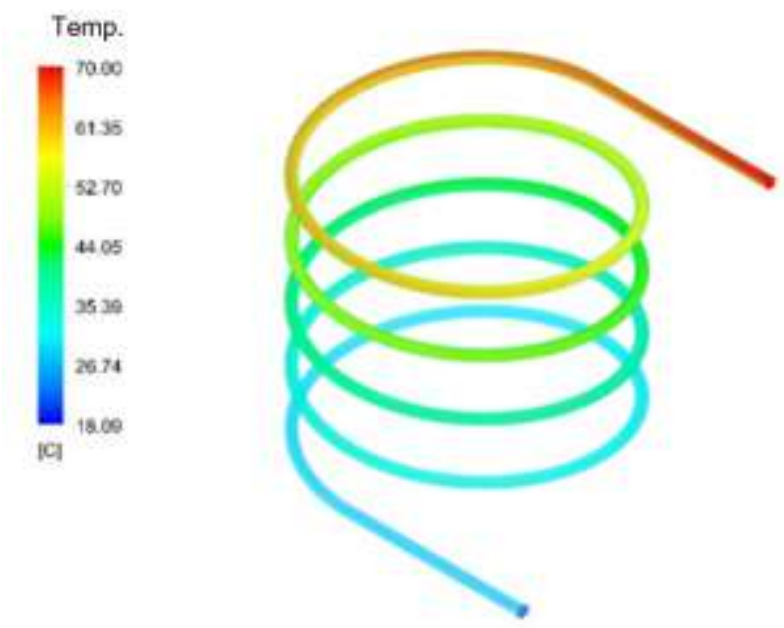

Fig. 10. Simulation 6 , behavior of the wort in the helical tube.

\section{CONCLUSIONS}

Considering the various parameters used for the simulations, better results for reducing the outlet temperature are obtained by changing the mass flow of the wort, where there is a variation of up to $15.16{ }^{\circ} \mathrm{C}$ when varying it from 0.7 to $0.2 \mathrm{~kg} \cdot \mathrm{s}^{-1}$. This by varying the water inlet temperature, where there is a maximum variation of $2.71^{\circ} \mathrm{C}$ and a minimum of $0.01^{\circ} \mathrm{C}$.

The mass flows of 0.2 and $7 \mathrm{~kg} \cdot \mathrm{s}^{-1}$ of the wort and water, respectively, are the ideal flows for the operation of the heat exchanger. The error obtained with respect to the mathematical calculations corresponds to $2.71 \%$, between an estimated temperature of $25^{\circ} \mathrm{C}$ and one obtained of $25.67^{\circ} \mathrm{C}$.

Future investigations of helical tube and shell heat exchangers should focus on the behavior and results when varying parameters such as the diameter and pitch of the propeller, since this study did not make considerable modifications to the initial dimensioning.

\section{AUtHORS' CONTRIBUTION}

Fernando Toapanta-Ramos: Conceptualization, Methodology, Investigation, Formal Analysis, Software, Validation, Writing - review \& editing.

Luis González-Rojas: Methodology, Investigation, Software.

Elmo Calero: Methodology, Investigation, Software. 
Numerical Study of a Helical Heat Exchanger for Wort Cooling in the Artisanal Beer Production Process

Bryan Calderón: Methodology, Investigation, Software.

William Quitiaquez: Methodology, Formal Analysis, Software, Validation.

\section{ACKNOWLEDGMENT}

The authors are especially grateful to the Research Group on Renewable Energies and Mechanical Implementation of SMEs, and the ASHRAE UPS-QUITO Branch of the Universidad Politécnica Salesiana, Quito-Ecuador.

\section{REFERENCES}

[1] A. L. de Azebedo-Delcor, "Análise Técnico-Econômica De Uma Indústria Cervejeira Artesanal," Master Thesis, Universidade Federal de Santa Catarina, Brazil, 2019.

[2] L. Rodhouse, F. Carbonero, "Overview of craft brewing specificities and potentially associated microbiota," Critical reviews in food science and nutrition, vol. 59 (3), pp. 462-473, 2019. https://doi.org/10.1080/10408398.2017.1378616

[3] S. H. Suqui, E. P. Morales, "Implementación de un sistema de fermentación para la elaboración de cerveza artesanal con la utilización de tres variedades de cebada," Grade Thesis, Universidad Politécnica Salesiana Sede Cuenca, Peru, 2015.

[4] A. Marcos, M. López Díaz-Ufano, V. Pascual Fuster, “¿El consumo moderado de cerveza podría incluirse dentro de una alimentación saludable?," SEMERGEN-Medicina de Familia, vol. 41 (Supl 1), pp. 1-12, 2015. https://doi.org/10.1016/S1138-3593(15)30006-X

[5] M. Mosher, K. Trantham, Brewing Science: A Multidisciplinary Approach, Springer International Publishing Switzerland, 2017.

[6] C. Tyrawa, R. Preiss, M. Armstrong, G. Van Der Merwe, "The temperature dependent functionality of Brettanomyces bruxellensis strains in wort fermentations," Journal of the Institute of Brewing, vol. 125 (3), pp. 315-325, 2019. https://doi.org/10.1002/jib.565

[7] A. D. Rodman, M. Weaser, L. Griffiths, D. I. Gerogiorgis, "Dynamic Optimisation and Visualisation of Industrial Beer Fermentation with Explicit Heat Transfer Dynamics," Computer Aided Chemical Engineering, vol. 46, pp. 1459-1464, 2019. https://doi.org/10.1016/b978-0-12-818634-3.50244-7

[8] A. D. Rodman, D. I. Gerogiorgis, "Multi-objective process optimisation of beer fermentation via dynamic simulation," Food and Bioproducts Processing, vol. 100, pp. 255-274, 2016. https://doi.org/10.1016/i.fbp.2016.04.002

[9] A. D. Rodman, D. I. Gerogiorgis, "Parameter estimation and sensitivity analysis for dynamic modelling and simulation of beer fermentation," Computers \& Chemical Engineering, vol. 136, e106665, 2020. https://doi.org/10.1016/j.compchemeng.2019.106665

[10] M. Gisbert Verdú, "Diseño del proceso industrial para la elaboración de cerveza," Grade Thesis, Universidad Politécnica de Valencia-Campus Alcoy, Spain, 2014.

[11] J. Alpízar Quirós, "Prefactibilidad técnica y financiera de una micro cervecería de cerveza artesanal," Master Thesis, Universidad de Costa Rica, Costa Rica, 2018.

Revista Facultad de Ingeniería (Rev. Fac. Ing.) Vol. 29 (54), e11632. 2020. Tunja-Boyacá, Colombia. L-ISSN: 0121-1129, e-ISSN: 2357-5328, DOI: https://doi.org/10.19053/01211129.v29.n54.2020.11632 
Fernando Toapanta-Ramos; Luis González-Rojas; Elmo Calero; Bryan Calderón; William Quitiaquez

[12] V. Agulló, "Efecto de lamaceración escalonada de la temperatura de fermentación en las propiedades funcionales de la cerveza," Master Thesis, Universidad Miguel Hernandez de Elche, Spain, 2015.

[13] J. A. Mocada, J. Bellina, H. D. Delgado, C. Escurra, S. P. Asalde, "Diseño de una línea de Producción para la elaboración de cerveza artesanal de algarroba," Universidad de Piura, Peru, 2015.

[14] J. A. Vladimir, M. M. Kukultzin, "Metodología De Cálculo Para El Diseño Térmico De Un Intercambiador De Calor Deplacas," Grade Thesis, Universidad Nacional Autónoma de México, Mexico, 2015.

[15] M. M. Sarafraz, V. Nikkhah, S. A. Madani, M. Jafarian, F. Hormozi, "Low-frequency vibration for fouling mitigation and intensification of thermal performance of a plate heat exchanger working with $\mathrm{CuO} /$ water nanofluid," Applied Thermal Engineering, vol. 121 (5), pp. 388-399, 2017. https://doi.org/10.1016/j.applthermaleng.2017.04.083

[16] A. A. Sánchez-Escalona, E. Góngora-Leyva, C. Zalazar-Oliva, "Predicción de la resistencia térmica de las incrustaciones en los enfriadores de ácido sulfhídrico," Minería y Geología, vol. 34 (3), pp. 90-100, 2018.

[17] D. Qu, D. Qiu, Draft beer machine, US Patent App. 15/418,677, 2018.

[18] X. Liu, F. Wang, Z. Li, C. Zhu, H. Zhang, H. Zhang, "Parametric investigation of thermal-hydrodynamic performance in the innovative helically coiled heat exchangers in the heat pump system," Energy and Buildings, vol. 216, e109961, 2020. https://doi.org/10.1016/j.enbuild.2020.109961

[19] G. Wang, T. Dbouk, D. Wang, Y. Pei, x. Peng, H Yuan, S. Xiang, "Experimental and numerical investigation on hydraulic and thermal performance in the tube-side of helically coiled-twisted trilobal tube heat exchanger," International Journal of Thermal Sciences., vol. 153, e106328, 2020. https://doi.org/10.1016/j.ijthermalsci.2020.106328

[20] E. M. S. El-said, M. Abdulaziz, M. M. Awad, "A numerical investigation on heat transfer enhancement and the flow characteristics in a new type plate heat exchanger using heli cal flow duct," Cogent Engineering, vol. 28, pp. 1-25, 2017. https://doi.org/10.1080/23311916.2017.1396638

[21] M. H. Seyyedvalilu, S.F. Ranjbar, "The Effect of Geometrical Parameters on Heat Transfer and Hydro Dynamical Characteristics of Helical Exchanger," International Journal Recent Advance Mechanical Engineering, vol. 4 (1), pp. 35-46, 2015. https://doi.org/10.14810/ijmech.2015.4104

[22] G. Wang, D. Wang, J. Deng, Y. Lyu, Y. Pei, S. Xiang, "Experimental and numerical study on the heat transfer and flow characteristics in shell side of helically coiled tube heat exchanger based on multiobjective optimization," International Journal of Heat and Mass Transfer, vol. 137, pp. 349-364, 2019. https://doi.org/10.1016/j.ijheatmasstransfer.2019.03.137

[23] Y. A. Cengel, A. J. Ghajar, Heat and Mass Transfer: Fundamentals and Applications, McGrawHill, 2015.

[24] O. Abushammala, R. Hreiz, C. Lemaître, É. Favre, "Optimal design of helical heat/mass exchangers under laminar flow: CFD investigation and correlations for maximal transfer efficiency and process intensification performances," International Journal of Heat and Mass Transfer, vol. 153, e119610, 2020. https://doi.org/10.1016/j.ijheatmasstransfer.2020.119610

Revista Facultad de Ingeniería (Rev. Fac. Ing.) Vol. 29 (54), e11632. 2020. Tunja-Boyacá, Colombia. L-ISSN: 0121-1129, e-ISSN: 2357-5328, DOI: https://doi.org/10.19053/01211129.v29.n54.2020.11632 